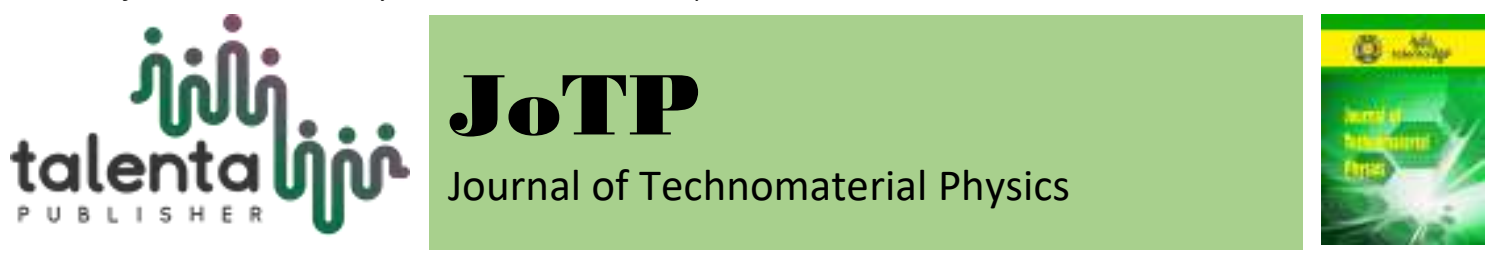

\title{
Physical Properties Analysis of Activated Carbon from Oil Palm Empty Fruit Bunch Fiber on Methylene Blue Adsorption
}

\author{
Rakhmawati Farma ${ }^{1}$, Fitri Wahyuni ${ }^{2}$ and Awitdrus ${ }^{3}$ \\ ${ }^{1,2,3}$ Department of Physics, Faculty of Mathematics and Natural Sciences, Universitas Riau, Pekanbaru \\ 28293, Indonesia
}

\begin{abstract}
The present research was conducted to analyze the physical properties of activated carbon from oil palm empty fruit bunch fiber (OPEFBF) to be applied as methylene blue adsorbent material. The OPEFBF was pre-carbonized at $280^{\circ} \mathrm{C}$ for 4 hours in vacuum, milled, and sieved to obtain the self-adhesive carbon grain (SACG) with a size less than $106 \mu \mathrm{m}$. The chemical activation was done using potassium hydroxide $(\mathrm{KOH})$ with variations of $25 \%, 50 \%$, and $75 \%$ from the SACG weight, stirred at $400 \mathrm{rpm}$ for 24 hours at room temperature and pyrolyzed using microwave irradiations at the output power of $720 \mathrm{~W}$ for 15 minutes. The physical properties of activated carbon consist of two characterizations, namely microstructure evaluated with X-ray diffraction (XRD) and surface morphology evaluated with scanning electron microscopy (SEM). The XRD pattern showed that the activated carbon had a semi-crystalline structure characterized by the presence of (002) and (100) plane s at the diffraction angle of $2 \theta$ about $21^{\circ}$ and $43^{\circ}$, respectively. The surface morphology of activated carbon depicted that a higher percentage of $\mathrm{KOH}$ resulted in more pores were formed. Thus, the higher the surface area of activated carbon, the greater the adsorption of methylene blue. The highest methylene blue adsorption was obtained in the sample of $75 \% \mathrm{KOH}$ with $87.73 \mathrm{mg} / \mathrm{g}$. The energy dispersive X-ray showed that the increase of $\mathrm{KOH}$ percentage used enhanced the percentage of carbon element produced.
\end{abstract}

Keyword: Oil Palm Empty Fruit Bunch Fiber, Chemical Activation, Activated Carbon, Physical Properties, Adsorption

Received 28 November 2018 | Revised [23 February 2019] | Accepted [28 February 2019]

\section{Introduction}

The textile industry is one of the fastest growing industries today. The textile industry uses methylene blue as a dye, so the industry produces waste with a relatively high content of methylene blue. The waste can damage the balance of the environmental ecosystem characterized by the contamination and death of aquatic organisms around the waste disposal site. Further waste processing is needed so that this waste is safe for the environment. One method which can be used to parse the waste is the adsorption method. Substances used in the

\footnotetext{
*Corresponding author at: Bina Widya Km 12.5 Simpang Baru Pekanbaru, 28293

E-mail address: rakhmawati.farma@lecturer.unri.ac.id
} 
adsorption process are known as adsorbents. Activated carbon is one of the most widely used adsorbents. Activated carbon is highly suitable to be used as an adsorbent because of the high specific surface area of activated carbon and relatively adequate and stronger pore size distribution; thus, activated carbon is widely used to control air pollution and water purification [1-5]. Furthermore, activated carbon is the first recognized adsorbent and has been widely used in industry. However, the cost of purifying water using activated carbon is still expensive; therefore, there is a demand to produce activated carbon at a lower cost [6].

The application of activated carbon from various types of biomass as an adsorbent has been studied extensively, such as oil palm empty fruit bunch fiber [7], pineapple skin [8] and cotton stalks [9]. In this study, the biomass used for the preparation of activated carbon is oil palm empty fruit bunch fiber (OPEFBF). Oil palm (Elaeis guineensis) is an important industrial plant which produces cooking oil, industrial oil, and biodiesel fuel. Oil palm produces waste, such as oil palm empty fruit bunches, palm fronds, and palm shells. The OPEFBF were pre-carbonized and activated using various percentages of $\mathrm{KOH}$ activators supported with microwave irradiation in order to obtain activated carbon which has a large surface area and high adsorption.

\section{Materials and Methods}

The preparation process of activated carbon from oil palm empty fruit bunch fiber (OPEFBF) with potassium hydroxide $(\mathrm{KOH})$ as the activator was done in two main processes, namely the pre-carbonization process and the activation process. The initial processes of preparing activated carbon were washing and separating OPEFBF so that the fibers were no longer clot. The precarbonization of OPEFBF was carried out at $280^{\circ} \mathrm{C}$ for 4 hours in a vacuum, grounded with ball milling for 36 hours, and sieved to obtain self-adhesive carbon grain (SACG) with a size of $\leq$ $106 \mu \mathrm{m}$. The activation of carbon used $\mathrm{KOH}$ activator with a variation of $25 \%, 50 \%$, and $75 \%$ of the SACG weight. The activation was performed for 25 hours and stirred with a magnetic stirrer at room temperature at a speed of $400 \mathrm{rpm}$. After the activation process, the sample was irradiated at a microwave power of $720 \mathrm{~W}$ for 15 minutes. The neutralization of activated carbon was done by washing it repeatedly with distilled water so that the $\mathrm{pH}$ was close to neutral. Activated carbon was then dried using an oven at $100^{\circ} \mathrm{C}$ for 24 hours. Finally, the last step was the characterization of activated carbon in order to determine the physical properties and adsorption of methylene blue. The activated carbon was characterized with X-ray diffraction, scanning electron microscopy, and energy dispersive X-ray.

\section{Result and Discussion}

\subsection{The Structure Analysis of Volcanic Rocks}

The X-ray diffraction (XRD) characterization aimed to determine the distance between planes, microcrystallite dimensions (stack height Lc and stack width La), and the number of layers. 
Figure 1 shows the X-ray diffraction pattern of the activated carbon before and after the chemical activation process with $\mathrm{KOH}$ activator. The sample without chemical activation was labeled with KA00. However, after chemical activation with $25 \% \mathrm{KOH}, 50 \% \mathrm{KOH}$, and $75 \%$ $\mathrm{KOH}$, the sample was labeled with KA25, KA50, and KA75, respectively. The XRD pattern showed that the activated carbon had a semicrystalline structure characterized by the presence of (002) and (100) planes each at a diffraction angle of $2 \theta$ around $21^{\circ}$ and $43^{\circ}$. The resulting diffraction pattern resembles the diffraction pattern produced by Farma et al. [10], Dolah et al. [11] and Awitdrus et al. [12] with oil palm empty fruit bunch biomass to be applied as supercapacitor cell electrodes. Figure 1 shows a diffraction peak shift at an angle of $2 \theta$ for all samples. This shift indicates a change in the distance between atoms which leads to a change in the distance between planes.

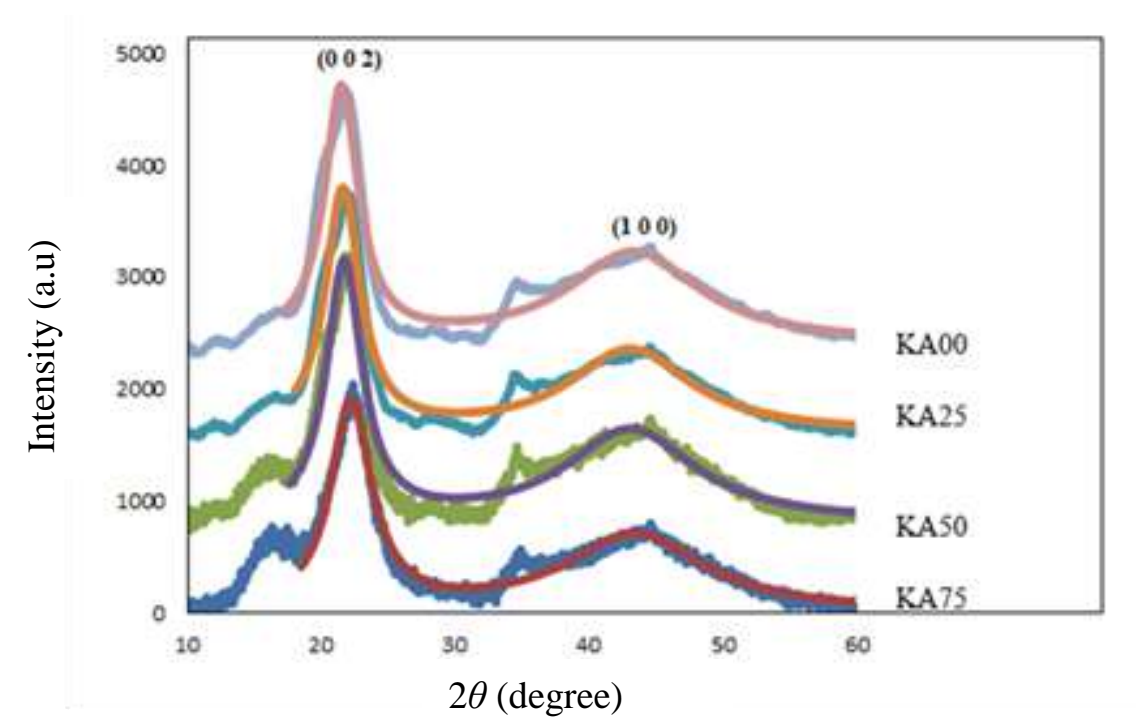

Figure 1. X-ray Diffraction Patterns Based on Variations in KOH Percentages

Table 1 shows interlayer spacing $\left(\mathrm{d}_{\mathrm{hkl}}\right)$ calculated using the Bragg equation, the stack height $\left(\mathrm{L}_{\mathrm{c}}\right)$ and stack width $\left(\mathrm{L}_{\mathrm{a}}\right)$ calculated using the Scherer equation, and the number of layers $\left(\mathrm{N}_{\mathrm{p}}\right)$ which is the ratio of $L_{c} / d_{002}$. The $L_{c}, L_{a}$, and $N_{p}$ had different values for each sample because there was a rearrangement of the carbon atoms in the vertical direction during the activation and extended the distance between carbon atoms. As a result, the resulting stack height value $\left(\mathrm{L}_{\mathrm{c}}\right)$ and the number of layers $\left(\mathrm{N}_{\mathrm{p}}\right)$ increased, but the stack width $\left(\mathrm{L}_{\mathrm{a}}\right)$ decreased. These results are consistent with the results found by Farma et al. [10].

Table 1. Interlayer Spacing and Dimension of Microcrystalline

\begin{tabular}{|c|c|c|c|c|c|c|c|}
\hline \multirow[t]{2}{*}{ Sample } & \multicolumn{2}{|c|}{$2 \theta\left(^{\circ}\right)$} & \multicolumn{2}{|c|}{$\begin{array}{c}\text { Interlayer } \\
\text { Spacing (nm) }\end{array}$} & \multicolumn{2}{|c|}{$\begin{array}{c}\text { Dimension of } \\
\text { Microcrystalline (nm) }\end{array}$} & \multirow{2}{*}{$\mathrm{N}_{\mathrm{p}}$} \\
\hline & $\left(\begin{array}{lll}0 & 0 & 2\end{array}\right)$ & $\left(\begin{array}{lll}1 & 0 & 0\end{array}\right)$ & $\mathrm{d}_{(002)}$ & $d_{\left(\begin{array}{lll}10 & 0\end{array}\right)}$ & $\mathrm{L}_{\mathrm{c}}$ & $\mathrm{L}_{\mathrm{a}}$ & \\
\hline KA00 & 22.211 & 42.421 & 0.399 & 0.212 & 2.300 & 1.058 & 5.753 \\
\hline KA25 & 21.017 & 42.837 & 0.422 & 0.210 & 2.757 & 1.400 & 6.528 \\
\hline KA50 & 21.111 & 43.481 & 0.420 & 0.207 & 2.808 & 1.408 & 6.679 \\
\hline KA75 & 21.713 & 43.714 & 0.408 & 0.206 & 2.897 & 1.250 & 7.085 \\
\hline
\end{tabular}


The KA00 sample had the lowest Lc value because KA00 was not activated so that the carbon pores have not been created and open. In contrast, the KA75 sample had the highest Lc and Np values but the lowest La value when compared to the KA25 and KA50 samples. The high Lc and $\mathrm{Np}$ values in the KA75 sample might be influenced by the number of $\mathrm{KOH}$ percentages used in which the more percentage of $\mathrm{KOH}$ used, the greater the $\mathrm{Lc}$ and $\mathrm{Np}$ values will increase. The increase in crystallinity occurs because there is an increasingly regular shrinkage of the activated carbon crystallite structure in which it will produce a wider gap between crystallites and form more pores [13].

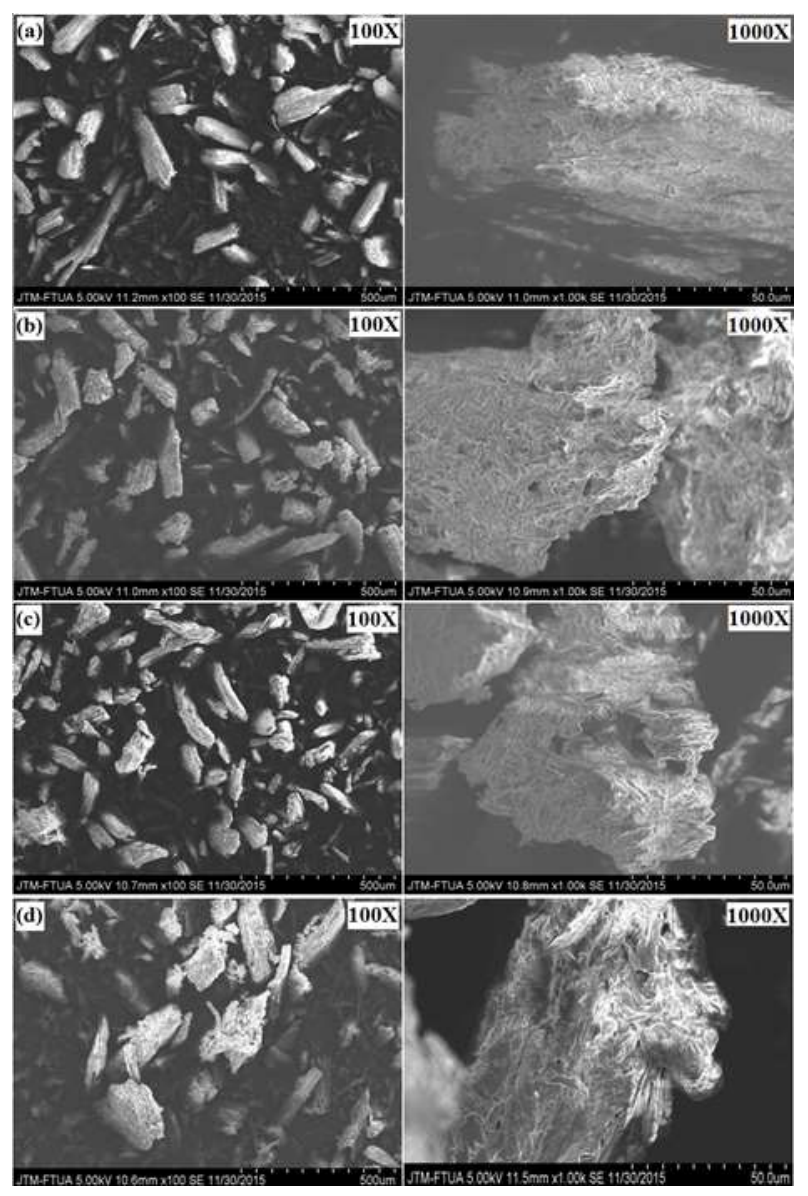

Figure 2. The Surface Morphology of Activated Carbon (a) KA00 (b) KA25 (c) KA50 and (d) KA75 Samples

The morphological characteristics of the activated carbon surface at 100 times and 1000 times magnification for the KA00, KA25, KA50, and KA75 samples can be seen in Figure 2. The KA00 sample showed irregular, smaller, and fewer pores. It occurred because impurities and volatile compounds still covered the pores on the carbon surface after the pre-carbonization process. The KA25 sample showed that the pores were starting to open and had more pores than the KA00 sample because the addition of $\mathrm{KOH}$ activator in the chemical activation process supported with microwave irradiation produced more pores on the activated carbon. The higher the percentage of $\mathrm{KOH}$ used in the chemical activation process, the more pores are formed. $\mathrm{KOH}$ is a strong base, so it can remove volatile compounds and tar which cover the pores on the carbon so that the pores formed will increase. The surface morphology of activated carbon after 
the chemical activation and microwave irradiation process had regular macropores. The pores became wider due to the loss of cavity part which was closed inside carbon particles [14].

The characterization of energy dispersive X-ray (EDX) was performed to determine the content of elements in the activated carbon and to determine the weight and atomic percentage from each element. Table 2 shows the content of elements contained in the activated carbon before and after the chemical activation process.

Table 2. Percentage of Elements Contained in the Activated Carbon

\begin{tabular}{cccccc}
\hline \multirow{2}{*}{ No. } & \multirow{2}{*}{ Sample } & \multicolumn{2}{c}{ Weight (\%) } & \multicolumn{2}{c}{ Atomic (\%) } \\
\cline { 3 - 6 } & & $\mathrm{C}$ & $\mathrm{O}$ & $\mathrm{C}$ & $\mathrm{O}$ \\
\hline 1. & KA00 & 42.92 & 57.08 & 51.08 & 48.92 \\
2. & KA25 & 51.43 & 48.46 & 58.42 & 41.38 \\
3. & KA50 & 53.43 & 46.45 & 60.56 & 39.44 \\
4. & KA75 & 54.89 & 45.11 & 61.84 & 38.16 \\
\hline
\end{tabular}

In Table 2, it can be seen that the carbon element in KA25, KA50, and KA75 samples increased compared to the KA00 sample before chemical activation. This is because the chemical activation process can remove impurities and gases contained in carbon so that activated carbon has high carbon content and low oxygen content. The percentage of carbon content in activated carbon increases as the percentage of $\mathrm{KOH}$ increases during the activation. The KA75 sample had the highest percentage of carbon weight and the smallest percentage of oxygen weight compared to KA25 and KA50 samples.

The content of carbon in this study was lower than the results of Ramdja et al [15-17] which produced $73.33 \%$ of carbon element with a coconut frond biomass carbonized at $500^{\circ} \mathrm{C}$. The low active carbon content indicates that the heating temperature is still low to convert cellulose, hemicellulose, and lignin to carbon. According to Marsh and Reinoso [14], carbon content can reach $90 \%$ when heated at $927^{\circ} \mathrm{C}$ and $99 \%$ when heated at $1327^{\circ} \mathrm{C}$, but it also depends on the biomass used.

The adsorption of activated carbon to methylene blue for KA00, KA25, KA50, and KA75 samples can be seen in Table 3. The adsorption capacity to methylene blue of the KA00 sample was $31.96 \mathrm{mg} / \mathrm{g}$. This adsorption value is extremely low compared to the carbon adsorption value after chemical activation. It might be because of the relatively low surface area of the KA00 activated carbon. The highest adsorption value was found in the KA75 sample with $87.731 \mathrm{mg} / \mathrm{g}$. The percentage of $\mathrm{KOH}$ affects the adsorption capacity of activated carbon to methylene blue in which the increase in the $\mathrm{KOH}$ percentage will produce greater methylene blue adsorption. These results are consistent with the results found by Erlina et al [18-20] that the higher percentage of activating agents given to carbon, the higher the adsorption capacity. 
Based on the results of methylene blue adsorption, the surface area of activated carbon can be calculated.

Table 3. Adsorption Capacity of Activated Carbon to Methylene Blue

\begin{tabular}{cccc}
\hline No. & Sample & Adsorption $(\mathrm{mg} / \mathrm{g})$ & Surface Area $\left(\mathrm{m}^{2} / \mathrm{g}\right)$ \\
\hline 1. & KA00 & 31.960 & 118.53 \\
2. & KA25 & 86.562 & 320.41 \\
3. & KA50 & 87.580 & 324.17 \\
4. & KA75 & 87.731 & 324.73 \\
\hline
\end{tabular}

The surface area of activated carbon is shown in Table 3. The surface area of activated carbon was calculated based on the adsorption capacity of methylene blue. The highest surface area was found in the KA75 sample which produced the greatest adsorption. The higher the percentage of $\mathrm{KOH}$ used, the more micropores and mesopores are formed which causes the surface area to increase.

\section{Conclusion}

The XRD pattern showed that the activated carbon had a semicrystalline structure characterized by the presence of (002) and (100) planes at an angle of $2 \theta$ around $21^{\circ}$ and $43^{\circ}$ respectively. The highest Lc value was obtained by the KA75 sample which had the highest percentage of the activator with $2.898 \mathrm{~nm}$ and the lowest La value with $1.255 \mathrm{~nm}$. Chemical activation affects the increased adsorption of activated carbon to methylene blue. The greater the percentage of $\mathrm{KOH}$ given, the greater the adsorption of carbon to methylene blue. The highest adsorption value was produced by the KA75 sample with an adsorption value of $87.731 \mathrm{mg} / \mathrm{g}$. However, the adsorption capacity in this study was not significant.

\section{REFERENCES}

[1] Y. Z. Zhuo, Y. Qi, L. Xiao-Ming, L. Kun, L. Yang and M. Z. Guang, "Preparation of Peanut Hull Based Activated Carbon by Microwave Induced Phosporic Acid Activation and Its Remazol Brilliant Blue R Adsorption," Industrial Crops and Product, vol. 37, pp. 178-185, 2012.

[2] J. Ding and et al, "Peanut shell hybrid sodium ion capacitor with extreme energy-power rivals lithium ion capacitors," Energy \& Environmental Science, vol. 8, no. 3, pp. 941-955, 2015.

[3] A. C. Martins and et al, "Removal of tetracycline by $\mathrm{NaOH}$-activated carbon produced from macadamia nut shells: kinetic and equilibrium studies," Chemical Engineering Journal, vol. 260, pp. 291-299, 2015.

[4] Y. Zhou, L. Zhang and Z. Cheng, "Removal of organic pollutants from aqueous solution using agricultural wastes: a review," Journal of Molecular Liquids, vol. 212, pp. 739-762, 2015.

[5] J. Georgin and et al, "Preparation of activated carbon from peanut shell by conventional pyrolysis and microwave irradiation-pyrolysis to remove organic dyes from aqueous solutions," Journal of Environmental Chemical Engineering, vol. 4, no. 1, pp. 266-275, 2016. 
[6] W. Li, L. Zhang, J. Peng, N. Li and X. Zhu, "Preparation of High Surface Area Activated Carbons from Tobacco Stems with K2CO3 Activation Using Microwave Radiation," Industrial Crops and Products, vol. 27, pp. 341-347, 2008.

[7] K. Y. Foo and B. H. Ahmeed, "Foo, K.Y. and Ahmeed, B.H. Microwave Assisted Preparation of Oil Palm Fiber Activated Carbon for Methylen Blue Adsorption," Chemical Engineering Journal, vol. 166, pp. 792-795, 2011.

[8] K. Y. Foo and B. H. Ahmeed, "Porous Structure and Adsorptive Properties of Pineapple Peel Based Activated Carbons Prepared Via Microwave Assisted KOH and K2CO3 Activation," Microporous And Mesoporous Materials, vol. 148, pp. 191-195, 2012.

[9] H. Deng, G. Zhang, X. Xu, G. Tao and J. Dai, "Optimization of Preparation of Activated Carbon from Cotton Stalk by Microwave Assisted Phosporic Acid-Chemical Activation," Journal of Hazardous of Materials, vol. 182, pp. 217-224, 2010.

[10] R. Farma, M. Deraman, Awitdrus, I. A. Tahlib, E. Taer, N. H. Basri, J. G. Manjhunata, M. M. Isbak, B. N. M. Dollah and S. A. Hashmi, "Preparation og Highly Porous Binderless Activated Carbon Electrodes from Fibres of Oil Palm Empty fruit Bunchess for Application in Supercapasitor," Biresource Technology, vol. 132, pp. 254-261, 2013.

[11] B. N. M. Dolah, M. Deraman, M. A. R. Othman, R. Farma, E. Taer, Awitdrus, N. H. Basri, I. A. Thalib, R. Omar and N. S. M. Nor, "A Method to Produce Binderless Supercapasitor Electrode monoliths from Biomass Carbon and Carbon Nanotube," Material Research Bulletin, vol. 60, pp. 10-19, 2014.

[12] Awitdrus, M. Deraman, I. A. Thalib, R. Omar, M. H. Jumaili, E. Taer and M. M. Saman, "Mycrocrystallite Dimension and Total Active Surface Area of Carbon Electrode from Mixture of Pre-carbonized Oil Palm Empty Fruit Bunches and Green Petroleum Cokes," Sains Malaysia, vol. 39, pp. 83-86, 2010.

[13] S. Wibowo, W. Syafi'i and G. Pari, "Karakterisasi Permukaan Arang Aktif Tempurung Biji Nyamplung," Makara Teknologi, vol. 15, no. 1, pp. 17-24, 2011.

[14] H. Marsh and R. F. Rodriguez, Activated Carbon, Netherlands: Elsevier Sciences and Technology Books, 2006.

[15] F. A. Ramdja, M. Halim and J. Handi, "Pembuatan Karbon Aktif dari Pelepah Kelapa.," Jurnal Teknik Kimia, vol. 15, no. 2, pp. 1-8, 2008.

[16] Esterlita, M. Olivia and N. Herlina, "Pengaruh penambahan aktivator $\mathrm{ZnCl} 2, \mathrm{KOH}$, dan H3PO4 dalam pembuatan karbon aktif dari pelepah aren (Arenga pinnata)," Jurnal Teknik Kimia USU, vol. 4, no. 1, 2015.

[17] Hayati, G. Indah, B. Pertiwi and Y. Ristianingsih, "Pengaruh Variasi Konsentrasi Adsorben Biji Trembesi Terhadap Penurunan Kadar Logam Kromium $(\mathrm{Cr})$ Total Pada Limbah Industri Sasirangan," Jurnal Konversi UNLAM, vol. 5, no. 2, pp. 1-4, 2018.

[18] U. Erlina and E. Budi, "Pengaruh Konsentrasi Larutan KOH pada Karbon Aktif Tempurung Kelapa Untuk Adsorpsi Logam Cu," in Prosiding Seminar Nasional FIsika, 2015.

[19] R. Farma, D. Fatjrin, Awitdrus and M. Deraman, "Physical Properties of Activated Carbon from Fibers of Oil Palm Empty Fruit Bunches by Microwave Assisted Potassium Hydroxide Activation," in AIP Conference Proceedings, USA, 2017.

[20] H. I. Naf'an, J. Sinto and Y. W. Nugroho, "Utilization of crown pineapple waste as raw material preparation of activated carbon as adsorbent in natural gas storage," E3S Web of Conferences, p. 67, 2018. 